\title{
PERSPEKTIF SANTRI DALAM KARYA SASTRA: SEBUAH REPRESENTASI WACANA RELIGIUS-HUMANIS
}

\author{
Irana Astutiningsih ${ }^{1}$, Hat Pujiati ${ }^{2}$ \\ FIB Universitas Jember \\ irananingsih@gmail.com ${ }^{1}$, hatpujiati.sastra@unej.ac.id ${ }^{2}$
}

\begin{abstract}
Abstrak
Pesantren kerap dicurigai sebagai lahan subur penyemai bibit radikalisme yang mengancam keutuhan bangsa dan negara, sejatinya sangat akrab dengan nilai-nilai yang humanis, yang salah satunya direpresentasikan dalam karya sastra pesantren. Kajian ini membincang representasi wacana religius-humanis dalam sastra pesantren sebagai objek material, berupa tiga cerita pendek berjudul "Di Antara Dua Pilihan", "Cinta Sejati Itu Tidak Mudah", dan "Seruas Bingung. Ketiganya" terbit di buletin Tanwirul Afkar, sebuah buletin salah pondok pesantren Salafiyah Syafi'iyah di Sukorejo, Jawa Timur. Oleh sebab itu, teori representasi Stuart Hall dipakai sebagai alat analisis. Terkait dengan pendekatan konstruksionis model diskursif Foucauldian yang bertitik tekan pada produksi pengetahuan melalui wacana yang melibatkan sistem bahasa, ketiga cerpen dianalisis dengan memetakan wacana religius-Humanis dan dikaitkan dengan latar kontekstual tempat wacana tersebut diproduksi. Hasil analisis menunjukkan bahwa dalam sastra pesantren konstruksi wacana religius-humanis dihadirkan melalui nilai- nilai kemanusiaan yang universal, alih-alih terjebak pada dikotomi yang rigid antara benar dan salah, sebagaimana pemahaman yang kerap memicu radikalisme. Nilai religius justru hadir seiring dengan nilai kemanusiaan universal sebagai satu representasi keberpihakan santri penulis terhadap wacana religius-humanis melalui sastra pesantren.
\end{abstract}

Kata Kunci: wacana; pesantren; sastra pesantren; religius-humanis; representasi

\begin{abstract}
Pesantren (Islamic Boarding School) is suspected as a fertile place for the radicalism which treat the united nations and states of Indonesia as a republic. As a religious school, pesantren is supposed to be representative for humanism since religion is taken as a living guide for human being. This article discusses representation of religious-humanist discourse in Pesantren Literature as the material object; they are short stories entitled: "Diantara Dua Pilihan", "Cinta Sejati Itu Tidak Mudah" dan "Seruas Bingung". The short stories were published in Tanwirul Afkar, a monthly bulletin in Salafiyah Syafi'iyah Islamic Boarding School at Sukorejo, Situbondo, East Java Indonesia. We apply Stuart Hall's representation theory as a tool to analyze the stories. Focusing on Foucauldian's discursive method in constructionist model that emphasizes on the knowledge production in discourses through language, we map the contextual background to find out the genealogy of religious-humanist discourse production. The result shows that religious-humanist discourses in Pesantren literary works are presented through universal human values, instead of being trapped in a rigid dichotomy between right and wrong that lead to a radicalism. Religiosity comes along with the universal human values as a representation of santri writers's partialit on religious-humanist discourse through Pesantren literature.
\end{abstract}

Keywords: discourse; pesantren; pesantren literature; religious-humanist; representation 
Poetika : Jurnal Ilmu Sastra

Vol. VII No. 1, Juli 2019
DOI 10.22146/poetika.40902

ISSN 2338-5383 (print) ; 2503-464 (online)

\section{Pendahuluan}

Karya sastra yang dalam pemahaman awam kerap dipahami sebagai karya fiktif yang berakar dari (sekadar) imajinasi pengarang, pada dasarnya selalu merepresentasikan wacana tertentu, dan terkait erat dengan segala persoalan dan kepentingan dalam masyarakat pada periode historis tertentu (Foucault, 1984;1981;1980). Implikasinya, karya sastra memiliki kemampuan mengonstruksi wacana-wacana spesifik yang ditujukan untuk kepentingan tertentu. Lebih jauh, karya sastra yang kerap dipahami sebagai produk dari satu wacana historis-kultural, sekaligus memproduksi dan mengonstruksi sebuah wacana secara historis-kultural. Jika karya sastra jamak dipahami dalam dimensi seni dan kemanusiaan sekaligus sebagai bagian dari industri kreatif yang kian marak, artikel ini mendiskusikan karya sastra yang lahir di pesantren yang jauh dari maraknya dunia industri. Dalam pandangan Jamal D. Rahman (Jamaldrahman.wordpress.com, Oktober 25, 2008), sastra pesantren didefinisikan dalam tiga pengertian yaitu; (1) sastra yang hidup di pesantren,...; (2) sastra yang ditulis oleh orang-orang (kiai, santri, alumni) pesantren; (3) sastra yang bertemakan pesantren, seperti Umi Kalsum Djamil Suherman, Geni Jora Abidah El-Khalieqy, dan Maria Maryam Parahdiba. Dengan tiga pengertian itu, khazanah sastra pesantren mengalami perluasan dan pengayaan, baik dalam bentuk, isi, maupun lingkungan pergaulannya." Sastra pesantren yang menjadi objek analisis tulisan ini hadir dalam genre cerita pendek yang terbit di buletin Tanwirul Afkar, sebuah buletin yang terbit di pesantren Salafiyah Syafi'iyah di Sukorejo, Situbondo, Jawa Timur.

Sebagai salah satu institusi pendidikan berbasis agama Islam, pesantren memiliki dua dimensi dalam menanamkan pemahaman nilainilai keagamaan terhadap para santrinya. Cakupan nilai-nilai tersebut mengatur hubungan manusia dengan Tuhannya (Habluminallah) sekaligus hubungan manusia dengan manusia lainnya (Habluminannaas). Sebagai implikasinya, nilai-nilai yang diajarkan di pesantren pada dasarnya meliputi nilai-nilai kemanusiaan yang mencakup persoalan tata krama, welas asih, toleransi, dan penghargaan terhadap orang lain. Dalam artikel yang berjudul "Nilai Humanisme Religius dalam Syiir Pesantren" oleh Muhammad Burhanudin (JSI 6 (1)2017) menyatakan bahwa Syiir, puisi klasik Jawa, yang berkembang di pesantren kental dengan nilai humanisme dan religiusitas karena tumbuh dan berkembang di lingkungan budaya agung. Pendidikan pesantren sebagai lembaga pendidikan tertua yang ada di Indonesia memiliki keberakaran pada budaya lokal yang dikelindankan dengan ajaran agama Islam. Sumber pengetahuan dan aturan akan agama Islam ada pada Alquran yang lahir di masa keemasan kesusatraan Arab sehingga bahasa Alquran pun dekat dengan bahasa sastra yang estetis. Oleh karena itu, pesantren dengan budayanya yang berpatokan pada ajaran Islam juga tidak jauh dari tradisi sastra 
dengan tetap menjadikan religiusitas sebagai materi utama dengan puncak kemanusiaan sebagai tujuan hidup. Sastra ini difungsikan sebagai hiburan, pendidikan, dan spiritual (Muzakkar via Burhanudin, 2017). Burhanudin (2017) mengemukakan bahwa syiir (sastra) sangat efektif sebagai media pendidikan dan pengajaran nilai humanis dan religius. Ekspresi nilai-nilai humanis dan religius dalam simulasi-simulasi terapan pengetahuan Islam yang kompleks kental dalam produk-produk kesusastraan di lingkungan pesantren. Sementara itu, fungsi spiritual dalam sastra merupakan ekspresi penghambaan diri kepada Tuhan (Burhanudin, 2017).

Namun ironisnya, pesantren dalam perkembangannya kerap kali dituding sebagai lahan subur untuk menyemai paham radikal yang berkontribusi terhadap konflik horizontal dengan sentimen agama sehingga berpotensi sebagai ancaman terhadap keutuhan Republik Indonesia. Hasil Riset yang dilakukan Wilson (2008) terkait konflik di Ambon menunjukkan bahwa dalam konflik yang dipicu politik identitas berbasis agama menciptakan kekacauan sosial dan tragedi berdarah. Agama yang idealnya hadir untuk menyebarkan pesan damai dan kemanusiaan, justru menjadi alat legitimasi kepentingankepentingan tertentu yang memicu konflik. Dengan kata lain, ketika satu kepentingan telah dibungkus isu dan label agama, kepentingan tersebut dianggap sebagai sebuah kebenaran yang mutlak sehingga menafikan, bahkan mengeliminasi kebenaran lain di luar dirinya. Dampaknya adalah stigma yang makin meluas dalam skala nasional ataupun internasional bahwa pesantren selalu identik dengan radikalisme. Di sinilah pentingnya dilakukan penelitian sebagai upaya memberikan alternatif pemikiran atau paradigma untuk menggugurkan doxa yang telah terbentuk dalam masyarakat terkait pesantren dan radikalisme. Melalui penelitian yang berjudul "Konstruksi Damai dalam Perspektif Santri: Model Kreativitas Sastra di Pesantren Berbasis Wacana ReligiusHumanistik untuk Pencegahan Radikalisme" ini, akan berusaha mencari konstruksikonstruksi religiusitas dan humanisme yang telah ada dalam karya sastra pesantren dan bisa dikembangkan untuk menciptakan masyarakat yang harmonis, alih-alih radikal. Artikel ini merupakan bagian dari penelitian tersebut.

Sebagaimana disinggung sebelumnya, artikel ini mendiskusikan nilai-nilai religiushumanis yang direpresentasikan dalam karya cerpen santri di pesantren Salafiyah Syafi'yah Situbondo dan diterbitkan di buletin Tanwirul Afkar. Pesantren salaf yang identik dengan konservatisme pemahaman agama dan kehatihatian dalam mengamalkan ajaran Islam yang diimplementasi dalam praktik kehidupan sehari-hari ini kerap memberikan latar depan (foreground) akan cara-cara yang kaku (rigid), bahkan menggiring pada kecurigaan tempat berkembangnya ajaran radikal. Melalui analisis tiga cerpen terpilih "Di Antara Dua 
Pilihan” (April 2013), “Cinta Sejati Itu Tidak Mudah" (April 2017), dan "Seruas Bingung" (Juni 2013) terbitan buletin Tanwirul Afkar di pondok pesantren Salafiyah Syafi'iyah Sukorejo, Jawa Timur akan digali wacana religius-humanis di dalamnya. Pertanyaan yang diusung dalam tulisan ini meliputi: 1) bagaimanakah wacana religius-humanis direpresentasikan dalam cerpen-cerpen karya santri? 2) posisi ideologis seperti apakah yang direpresentasikan oleh santri penulis sebagai bagian dari wacana tersebut? Lebih lanjut akan dijelaskan bagaimana teori representasi Stuart Hall dipakai sebagai alat analisis.

\section{Representasi Wacana dalam Teks Sastra: Sebuah Kerangka Teoritis}

Membincang representasi wacana dalam teks sastra pada dasarnya adalah berbicara tentang bagaimana suatu makna dikonstruksi melalui sistem representasi. Dengan kata lain, makna diproduksi dan dipertukarkan melalui sistem representasi yang merupakan dua proses relasional: mental representation dan language representation (Hall, 1997). Menurut Hall, pada proses mental representation makna ditentukan oleh relasi antara objek dan sistem konseptual atau imaji yang terbentuk dalam pikiran, yang karenanya kita mampu mengenali 'dunia'. Lebih jauh, sistem konseptual yang terbentuk harus diterjemahkan dalam satu sistem penandaan (bahasa) agar dapat terhubung dengan objeknya. memungkinkan adanya relasi antara objek, konsep, dan tanda inilah yang dinamakan sistem representasi.

Dalam pandangan Hall, ada tiga pendekatan representasi; reflektif, intensional, dan konstruksionis (1997:24-25). Dalam pendekatan reflektif, makna terletak atau melekat pada objek sehingga dapat dikatakan bahwa bahasa berfungsi seperti cermin dengan merefleksikan makna yang sudah ada atau bekerja menirukan realitas. Sementara dalam pendekatan intensional, makna bergantung pada author. Dua pendekatan ini memiliki kelemahan terkait dengan persoalan yang tak mampu diselesaikan keduanya. Dalam pendekatan reflektif, misalnya, timbul pertanyaan apakah semua hal yang dapat diungkap melalui bahasa dapat ditemukan dalam realitas? Lebih jauh, mampukah 'realitas' menjelaskan perbedaan persepsi antar orang dengan latar kultural (bahasa) yang berbeda? Sedangkan dalam pendekatan intensional, timbul persoalan karena pada kenyataannya bahasa tidak semata-mata berfungsi dalam wilayah personal, karena seberapapun personalnya maksud satu pengarang, ia harus memenuhi kode, aturan dan kesepakatan linguistik untuk dapat dipahami bersama. Kelemahan dua pendekatan ini dapat diatasi melalui pendekatan yang ketiga yaitu konstruksionis. Dalam perspektif ini, makna diproduksi melalui sistem representasi yang disebut 'bahasa' (Hall 1997:28). Dengan kata lain, representasi merupakan produksi makna melalui bahasa. 
Masih dalam pandangan Hall, representasi dalam perspektif konstruksionis memiliki dua model, yakni semiotik yang berakar dari tradisi Saussurean dan diskursif yang berakar dari pemahaman Foucauldian. Jika model semiotik bertitik tekan pada bagaimana bahasa memproduksi makna melalui praktik penandaan, model Foucauldian yang dipakai dalam analisis ini bertitik tekan pada bagaimana pengetahuan diproduksi melalui wacana pada keseluruhan formasi diskursifnya. Wacana dalam Foucault tidak dibatasi pada konsep linguistik murni, tetapi menjembatani apa yang dikatakan (language) dan apa yang dilakukan (practice). Model Foucauldian yang berada dalam perspektif konstruksionis ini tidak menafikan objek, tetapi percaya bahwa makna atau pengetahuan terhadap suatu objek dikonstruksi dalam satu formasi diskursif. Mengutip Foucault, Hall menggarisbawahi bahwa segala sesuatu bermakna dan benar dalam satu konteks historis yang partikular (Hall, 1997:46).

Dalam analisis wacana partikular pada teks sastra, ada beberapa hal penting yang perlu diperhatikan. Di antaranya adalah makna tidak melekat pada 'teks' sastra itu sendiri, tetapi terikat dengan konteks kultural yang melatarinya. Posisi pengarang bukan sebagai sentral (yang serba tahu), tetapi bagian dari kultur yang mengonstruksi makna tertentu melalui sistem representasi (bahasa). Yang terpenting, dalam pendekatan konstruksionis model Foucauldian, analisis wacana dalam teks sastra selalu terkait dengan persoalan produksi pengetahuan dan relasi kuasa. Dengan demikian, cerita pendek sebagai salah satu subgenre karya sastra dalam tulisan ini dipandang sebagai satu representasi yang pemaknaannya dilihat secara diskursif mengikuti model Foucauldian; melihat konstruksi makna dalam teks dan relasinya dengan hal-hal di luar teks tempat pengarang merupakan bagian darinya. Walaupun demikian, jejak penandaan yang dijadikan pijakan pembuktian dalam analisis representasi ini tidak bisa lepas dari tanggung jawab poetikanya. Langkah semiotis sebelum diskursif yang merupakan wilayah kontekstual dalam menghadirkan bagian-bagian teks untuk melihat keterikatan diskursifnya tetap dibutuhkan sebagaimana Henrietta Lidchi dalam Artikelnya yang berjudul "Poetics and Politics of Exibiting of Other Cultures" paparkan. Dalam antologi yang dieditori Stuart Hall, Representation: Cultural Representations and Signifying Practices, Lidchi melengkapi apa yang dipaparkan Hall akan konstruk sebuah representasi. Tanggung jawab tekstual dilihat dalam semiotika Barthesian yang menggunakan dua level pemaknaan, denotatif dan konotatif, yang kemudian dihubungkan pada hal-hal di luar teks sebagai wilayah kontekstual.

\section{Wacana Religius-humanis dalam Sastra Pesantren}

Di cerita pendek berjudul "Di Antara Dua Pilihan" yang diterbitkan di buletin Tanwirul 
Poetika : Jurnal Ilmu Sastra

Vol. VII No. 1, Juli 2019
DOI 10.22146/poetika.40902

ISSN 2338-5383 (print) ; 2503-464 (online)
Afkar edisi April 2013, dikisahkan tentang sebuah pilihan yang harus diputuskan oleh Indy, seorang mahasiswi yang hamil dengan pacarnya dan bermaksud menggugurkan kandungannya. Dalam upayanya menggugurkan janin yang dikandungnya, Indy meminta bantuan teman sekolahnya, Nanang, yang kini tengah menempuh pendidikan di pesantren. Nanang yang pada awalnya bersepakat untuk mencarikan Indy seorang dukun, ternyata hanya mengulur waktu agar Indy membatalkan niatnya untuk menggugurkan janin yang dikandungnya. Ia berpura-pura mengenal seorang dukun yang mau menggugurkan kandungan hanya agar janin yang dikandung Indy dapat tertolong.

Sebagai sebuah karya santri, isu yang diangkat dalam cerpen tersebut dapat dikatakan cukup berani dengan tidak membatasi diri pada stigma-stigma negatif yang dilegitimasi oleh cuplikan ayat-ayat kitab suci Alquran ataupun hadits meski nuansa religius tidak serta merta ditinggalkan. Jika jamak diketahui bahwa perempuan yang hamil di luar nikah dalam masyarakat patriarkal cenderung diposisikan sebagai yang lebih bersalah, membawa aib, dan karenanya layak untuk dihakimi, bahasa yang diusung dalam cerpen ini jauh dari stigma negatif dan penghakiman terhadap perempuan yang kerap diwakili oleh bahasa stigmatik, seperti 'perempuan laknat', 'haram jadah', ataupun 'perempuan jalang'. Sebagai seorang santri yang sehari-harinya sangat akrab dengan nilai-nilai religius, Nanang tidak sekalipun berupaya menghakimi Indy.

"Kamu betul-betul tahu dukun yang bisa menggugurkan kandungan ini, Nang?" Indy memastikan.

"Iya.., saya tahu. Tapi apa kamu tak mau mempertimbangkan keputusanmu lagi?" Nanang terus menanyakannya. Sebisa mungkin ia ingin menyelamatkan bayi yang ada dalam kandungan Indy itu (Tanwirul Afkar ed. 505 April 2013).

Sebagai seorang santri, bukan hal yang mudah bagi Nanang untuk menyanggupi permintaan temannya mencarikan seorang dukun yang mau menggugurkan kandungan. Meski kesanggupan Nanang mengantar Indy menemui dukun tersebut hanya sekadar taktiknya untuk mengulur waktu demi menyelamatkan si janin, apa yang dilakukan Nanang bukan tanpa risiko. Mengantar perempuan yang bukan muhrim (meski mereka naik motor secara terpisah) menemui dukun bukan hal yang 'akrab' digeluti santri, lebihlebih lagi dengan berbohong. Dengan kata lain, akan lebih mudah bagi Nanang untuk menolak secara tegas permintaan Indy dengan berbagai alasan dogmatis. Bagaimanapun, Nanang memilih bersikap lebih humanis terkait kondisi sulit yang dialami Indy. Alih-alih menghakimi Indy dan melabelinya dengan stigma negatif, Nanang memilih untuk 'bersiasat' demi kelangsungan hidup janin di kandungan Indy.

\footnotetext{
"Apalagi yang harus dipertimbangkan, Nang?"

"Setidaknya kamu masih mencoba berfikir, bagaimana seandainya bayi yang kau kandung itu yang akan membawamu ke surga, bagaimana jika bayi itu kelak menjadi anak sholeh yang akan mendoakanmu saat kamu telah tiada," Nanang mencoba untuk menasehatinya" (Tanwirul Afkar ed 949 April 2013).
} 
Poetika : Jurnal Ilmu Sastra

Vol. VII No. 1, Juli 2019
DOI 10.22146/poetika.40902

ISSN 2338-5383 (print) ; 2503-464 (online)
Bahasa yang dihadirkan dalam cerpen "Di Antara Dua Pilihan" tidak terjebak pada istilah stigmatik yang berkisar antara 'dosa' dan 'pahala' serta jauh dari kesan menggurui. Nasihat yang disampaikan Nanang pada Indy juga tidak semata-mata hadir dalam kerangka penghakiman dengan merujuk pada ayat-ayat kitab suci maupun hadits. Lebih jauh, wacana humanis dalam cerpen tersebut hadir dalam ilustrasi kutipan berikut:
“...Aku malu menanggung aib ini, justru bayi inilah yang akan memburamkan masa depanku," Indy menyahut, ia masih kukuh dengan pendiriannya.
"Kenapa kamu hanya memikirkan masa depanmu, padahal bayi itu juga berhak menikmati masa depan yang cerah seperti yang kau impikan," nada suara Nanang mulai meninggi, mungkin ia merasa kesal.
“... kamu saja mampu membuktikan cintamu pada pacarmu yang sebenarnya ia bukan siapa-siapa. Kenapa sekarang kau tidak bisa membuktikan cintamu pada janinmu yang sebenarnya ia darah dagingmu sendiri?"

Rencana Indy menggugurkan kandungannya dinilai Nanang sebagai sebuah ketidakadilan bagi si janin. Pandangan humanis direpresentasikan sebagai sebuah pilihan untuk mencintai si janin, memberinya kesempatan untuk lahir, hidup dan tumbuh berkembang sesuai haknya sebagai manusia. Pikiran Nanang mewakili apa yang semestinya dilakukan sebagai satu sikap adil oleh seorang terpelajar, sebagaimana yang dikatakan Pramoedya, bahwa seorang terpelajar harus sudah berbuat adil sejak dalam pikiran apalagi dalam perbuatan. Tanpa melalui bahasa penghakiman dan stigma negatif dengan dalil-dalil yang tidak terbantahkan, wacana religius-humanis hadir dalam teks tersebut. Nilai religius khas pesantren yang tidak sama sekali ditinggalkan, seperti dikatakan sebelumnya, tampak pada ilustrasi berikut ketika Sholeh sebagai teman Nanang sepesantren membenarkan tindakan Nanang.
"Kamu sudah membujuk Indy untuk memilih dengan tepat. Dan itu sesuai dengan kaidah fikih yang kemarin kita pelajari. "
“...apabila ada dua mafsadat bertentangan maka mafsadat yang lebih beratlah yang diperhatikan agar tidak terjadi dengan memilih melakukan mafsadat yang lebih ringan..." (Tanwirul Afkar ed. 505 April 2013).

Nuansa religius pesantren menguat dalam teks ketika Sholeh merujuk pada kaidah fikih yang mereka pelajari. Mafsadat (keburukan) yang dinilai lebih berat, dalam konteks ini menggugurkan janin di kandungan Indy, harus dihindari karena ini berarti menghilangkan hak hidup janin yang belum lahir. Di teks cerpen ini, pemahaman religius para santri yang taat dengan aturan fikih memberi prioritas lebih pada hak hidup manusia. Religiusitas dalam teks ini tidak mengarah pada nilai-nilai radikal seperti yang jamak ditudingkan pada pesantren, tetapi sebaliknya, yaitu mengedepankan nilai humanis yang berkeadilan dan menghargai hak hidup manusia. Menurut Mursalin (2010:261) eksklusivisme mengarahkan penganut sebuah ajaran untuk tidak toleran terhadap perbedaan dan kemajemukan. Eksklusivisme juga bisa ditarik ke titik ekstrem dengan berbuat kekerasan, baik intelektual, psikologis, maupun 
Poetika : Jurnal Ilmu Sastra

Vol. VII No. 1, Juli 2019
DOI 10.22146/poetika.40902

ISSN 2338-5383 (print) ; 2503-464 (online) fisik, terhadap siapa pun yang dianggap berbeda. Para subjek Islam radikal dalam memahami ajaran Islam telah melupakan bahwa Islam tidak sekadar dipahami sebagai teks (nash), tetapi juga dipahami sebagai sejarah (tarikh) yang tidak menafikan ruang/ tempat dan adat-istiadat. Artinya, interpretasi terhadap teks (nash Alquran) sangat memengaruhi pemikiran radikal atau tidaknya seseorang dalam beragama (Islam) (Mursalin, 2010:259-260). Akan tetapi, hadirnya wacana religius-humanis yang bersifat inklusivisme dan pluralisme seperti pada dialog Nanang dan Indy yang mana Nanang tidak serta-merta menghakimi perbuatan Indy, tokoh Nanang hadir membawa solusi yang tidak memperkeruh keadaan. Tokoh Nanang mampu menyerap ajaran tidak secara literal dan skriptural, melainkan melihat dan memahami konteks permasalahan Indy. Dengan demikian, teks cerpen ini tidak mengonversi sisi kemanusiaan secara kaku ke dalam dalil-dalil agama yang diusung dalam cerita. Paham radikal terhadap nilai religius pun gagal dengan memecahkan ekslusivitas pengetahuan agama ke dalam pluralitas permasalahan kemanusiaan sebagai konteks.

Cerpen lain berjudul "Cinta Sejati Itu Tidak Mudah" juga mengonstruksi wacana religius-humanis melalui persoalan dilematis seorang santri perempuan bernama Husna yang tengah menjalin hubungan jarak jauh dengan tunangannya, Ustaz Azka. Husna dihadapkan pada pilihan antara mempertahankan hubungannya dengan Ustaz Azka atau menerima tawaran Bu Nyai untuk dijodohkan dengan Ustaz Fikri.
"Begini Nak, saya cuma mau bertanya baik-baik. Kamu mau tah dijodohkan dengan ustad Fikri yang barusan?"
“... Setelah pulang dari dhalem, hati Husna penuh dengan dilema. Di satu sisi ia tidak ingin mengecewakan $\mathrm{Bu}$ Nyai yang selama ini membimbingnya, di sisi lain ia tidak tidak bisa berbohong dari kenyataan bahwa ia sudah memiliki tunangan, ... (Tanwirul Afkar ed. 532 April 2017).

Dalam Pujiati (2014), kepatuhan terhadap sosok Bapak Guru Ratoh dalam kultur Madura merupakan keutamaan. Bagaimanapun, teks cerpen terbitan salah satu pesantren di Situbondo yang kental dengan kultur Madura ini mengonstruksi satu upaya negosiatif terhadap kepatuhan tersebut. Ini terlihat ketika Husna memilih untuk mempertahankan hubungannya dengan tunangannya, Fikri.

\begin{abstract}
"Ya itu masalahnya Fin, aku harus menolak lamaran ustad Fikri karena aku sudah tunangan dengan mas Azka. Kamu ingat kan kaidah fikih yang kita pelajari. Sesuatu yang sibuk tidak boleh disibukkan lagi, sama saja kan dengan orang yang bertunangan tidak boleh menerima lamaran orang lain." (Tanwirul Afkar ed. 532 April 2017)
\end{abstract}

Senada dengan cerpen sebelumnya, wacana religius khas pesantren hadir dalam teks ini melalui kaidah fikih yang dipelajari Husna. Yang cukup berani diangkat sebagai isu dalam cerpen ini adalah bagaimana kepatuhan seorang santri terhadap gurunya pada akhirnya 'dikalahkan' oleh cinta murid kepada tunangannya. Uniknya, kaidah fikih tentang 'sesuatu yang sibuk' dipersepsi Husna dalam kerangka relasi personalnya dengan dengan 
Poetika : Jurnal Ilmu Sastra

Vol. VII No. 1, Juli 2019
DOI 10.22146/poetika.40902

ISSN 2338-5383 (print) ; 2503-464 (online)
Fikri. Dengan kata lain, nilai humanis direpresentasikan melalui pilihan yang berpihak pada hubungan asmara dua manusia dewasa, alih-alih pada kepatuhan pada guru sebagai satu hal yang sangat khas santri.

Dalam cerpen "Seruas Bingung", dikisahkan seorang santriwati bernama Lailiyah yang tengah berduka karena kematian ibunya. Yang menarik dari cerpen ini adalah ketika salat berjamaah sebagai ritual rutin dilakukan para santri, hingga menjadi semacam kewajiban, ditinggalkan oleh Lily karena kondisi kesehatannya. Tak berbeda dengan dua cerpen lainnya, nilai humanis dalam cerpen ini muncul seiring dengan nuansa religius khas pesantren.

“Lily, kalau sakit jangan paksain jama'ah".

"Kan Lily juga pingin keutamaan, kak" kembali kak Nuri mengulum senyum sambil menggeleng.

"Mencegah bahaya lebih utama dari menarik kebaikan Ly. Masih ingat waktu ustadzah Mufidah menerangkan kaidah itu, kan?"

(Tanwirul Afkar ed. 506 Sya'ban 1434 H).

Kaidah yang dijelaskan oleh ustazah mereka menjadi 'pembenar' ketidakikutan Lily dalam salat berjamaah. Sebagai senior yang lebih lama mengenyam pendidikan di pesantren, sosok Nuri dengan bijak menyikapi rasa bersalah Lily yang tidak ikut berjamaah. Lebih jauh, nuansa religius yang menyoal pahala salat hadir dalam kutipan berikut.

"Tapi kan sholat jumat dan jamaah mengandung pahala besar banget kak?" si kecil Lina mulai kritis.

"Pertanyaan yang bagus dik. Shalat jumat dan jamaah memang memiliki maslahah atau kebaikan yang mengandung pahala besar, tapi bila penyakit menjadi semakin parah atau keamanan jiwa terancam yang keduanya merupakan mafsadah/kerusakan, maka mencegah hal-hal yang tidak diinginkan lebih diutamakan"

(Tanwirul Afkar ed. 506 Sya'ban 1434H).

Alih-alih bersikap rigid dan dogmatis tentang keutamaan salat berjamaah, Nuri mengangkat persoalan kesehatan sebagai prioritas utama. Pemahaman akan agama pada cerpen ini tidak semata-mata mengerucut pada persoalan hubungan manusia dengan Tuhannya melalui ritual salat berjamaah yang bersifat mutlak, tetapi juga pada pemosisian manusia yang secara fitrah memiliki berbagai kekurangan.

Ketika pesantren kerap dituding sebagai lahan subur penyemai bibit radikal yang cenderung intoleran terhadap keberagaman, ini tampaknya terkait erat dengan asumsi bahwa dunia pesantren adalah dunia yang dibatasi oleh dogma yang kaku dan tidak dapat ditawar. Dengan kata lain, kebenaran dalam perspektif pesantren adalah kebenaran yang mutlak tunggal karena dilegitimasi oleh ayat-ayat kitab suci Alquran maupun hadits yang tidak menyisakan sedikit pun ruang untuk interpretasi. Pada kenyataannya, apa yang direpresentasikan oleh ketiga cerpen sebagai objek materi tulisan ini menunjukkan hal yang berbeda dengan asumsi di atas. Ketiga cerita pendek tersebut merepresentasikan wacana kemanusiaan dengan nilai toleransi dan jauh dari penghakiman dogmatis-tekstual.

Dalam cerpen "Di Antara Dua Pilihan" 
misalnya, persoalan hamil di luar nikah dihadirkan bukan untuk dihujat dan diancam hukuman cambuk dengan merujuk secara kaku pada dalil-dalil yang bersumber dari Alquran dan Hadits, tetapi lebih pada upaya memanusiakan manusia dengan bersikap adil terhadap janin yang juga memiliki hak hidup. Jika nilai Humanis dalam "Cinta Sejati Itu Tidak Mudah" direpresentasi melalui hubungan asmara yang mendapat prioritas lebih daripada kepatuhan santri kepada gurunya, maka dalam "Seruas Bingung" hak individu untuk menjaga keselamatan dan kesehatannya diberi ruang yang cukup luas dengan "menggugurkan" kewajiban salat berjamaah. Dengan mengangkat persoalan yang beragam, benang merah dari ketiga cerita pendek tersebut terletak pada wacana pemosisian manusia sebagai subjek yang mempunyai pilihan atas tindakannya, bukan semata-mata sebagai manusia yang didisiplinkan oleh aturan agama yang dogmatis, sekalipun agama jamak dipahami sebagai institusi yang mengatur individu dan masyarakat melalui penyeragaman, baik perilaku, bahasa, pakaian, maupun ritus (Haryatmoko, 2015:20). Ini dapat dilihat pada permasalahan personal yang dialami oleh karakter utama. Lebih jauh, tampak bahwa persoalan-persoalan kemanusiaan yang diangkat dalam ketiga cerita pendek tersebut dihadirkan bukan dalam kerangka pikir yang berkutat pada yang benar atau salah, tetapi disikapi secara proporsional dan ditempatkan dalam kerangka yang konstektual. Sekalipun demikian, ini tidak berarti bahwa religiusitas tidak lagi mendapat ruang, tetapi justru dapat berjalan seiring dengan nilai humanis yang dihadirkan dalam teks. Bahasa yang dihadirkan dalam teks adalah bahasa yang mengonstruksi nilai-nilai yang berpihak pada kemanusiaan dengan tetap memperhatikan nilai religius. Dengan kata lain, nilai Habluminallah dan Habluminanaas berjalan seiring dalam teks sehingga dapat dikatakan bahwa sastra pesantren yang diwakili oleh ketiga cerita pendek tersebut mengonstruksi wacana religius-humanis melalui representasi bahasanya dan dengan demikian, jauh dari radikalisme yang kerap ditudingkan.

Wacana dalam paham Foucauldian terbentuk melalui formasi diskursif yang particular. Sebuah wacana akan bermakna dan diterima sebagai sebuah kebenaran hanya dalam konteks historis tertentu. Ini berarti bahwa memahami wacana dalam teks sastra menuntut pula pemahaman akan wacana historis partikular yang melatarinya. Dengan kata lain, wacana pada teks akan terkait erat dengan wacana di luar teks yang turut mengonstruksi satu makna atau memproduksi pengetahuan dalam istilah Foucault. Dengan demikian, dapat dipahami bahwa konstruksi wacana religius-humanis dalam cerita pendek karya santri yang dijadikan objek analisis dalam tulisan ini berkaitan dengan wacana religius-humanis di luar cerita tersebut, dalam hal ini pengetahuan yang diproduksi dalam latar dunia pesantren khususnya pesantren 
Salafiyah Syafi'iyah Sukorejo, tempat buletin Tanwirul Afkar diterbitkan. Sebagai salah satu pesantren terbesar di Jawa Timur yang didirikan K.H. Syamsul Arifin pada 1908, pesantren ini meliputi lembaga pendidikan agama dan pendidikan umum dari tingkat Sekolah Dasar hingga Perguruan Tinggi. Sebagai pesantren salaf yang sangat ketat berpegang pada aturan dan hukum Islam, menarik untuk dicermati bahwa wacana ketuhanan dan kemanusiaan tumbuh beriringan secara harmonis sebagaimana direpresentasikan dalam karya sastranya.

Produksi pengetahuan akan ketuhanan dan kemanusiaan di lingkungan pesantren ini mengarah pada antiradikalisme. Studi kasus yang dilakukan Mursalin, dkk (2010) berjudul "Pola Pendidikan Keagamaan Pesantren dan Radikalisme: Studi Kasus Pesantren-pesantren di Provinsi Jambi" menemukan bahwa pengikut gerakan radikalisme terdiri dari penduduk desa yang bermigrasi ke kota atau masyarakat yang berstrata sosial rendah dan kebanyakan mereka merupakan kalangan generasi muda Islam yang tumbuh di bawah sistem pemerintahan nasional-sekuler. Sastra pesantren yang ditulis dalam Tanwirul Afkar ditulis oleh peserta didik yang masih belia dan dikonsumsi mereka yang ada di lingkungan pesantren oleh mereka yang juga masih muda dan berasal dari berbagai kalangan sosial. Absesnya radikalisme dalam tulisan mereka ini tidak lepas dari peran pemimpin pesantren. Semua yang beredar di dalam pesantren, buku-buku yang dikonsumsi santri telah melalui sensor ideologi. Ada tim yang mendistribusi buku, toko buku di lingkungan pesantren untuk menyaring buku yang masuk. Mereka mendapat amanah pimpinan pesantren untuk hati-hati terhadap buku-buku dengan ideologi yang tidak sejalan dengan apa yang diterapkan di pesantren (Zia, 2017). Jadi mereka hanya menjual buku-buku yang mereka kategorikan aman secara ideologis. Alasan di balik itu cukup sederhana, yaitu menguatkan nasionalisme dan keimanan dengan mengedepankan kemausiaan pada mereka yang masih muda. Kelak ketika mereka keluar dari pesantren dengan pondasi yang kuat maka tidak dikhawatirkan lagi ketika mereka terpapar berbagai ideologi yang semula dilarang di dalam pesantren tersebut dan tidak mudah terbawa arus karena sudah memiliki perangkat sensor otomatis dalam diri mereka.

Sejarah Pesantren Salafiyah Syafi'iyah yang dipimpin oleh orang-orang yang menganut paham keagamaan dengan tradisi belajar yang militan tak dapat dimungkiri telah turut andil dalam konstruk paham religius-humanis dalam cerpen-cerpen penulis muda di tahun 20132017an. Kiai Samsul Arifin sebagai pendiri Ponpes juga dilahirkan dari keluarga konservatif dalam hal keagamaan yang kemudian mengirim beliau ke Mekkah untuk belajar, berguru ke beberapa pesantren di Jawa yang menguatkan hubungan beliau dengan tradisi. Dilanjutkan oleh Kiai As'ad yang tak lain salah satu pendiri NU di Indonesia. Perjuangannya membela nusantara pun 
mengantar beliau sebagai salah satu pahlawan Nasional. Kemudian dilanjutkan putra beliau, yaitu Kiai Fawaid yang juga mencintai seni dan budaya, bahkan beliau mendirikan grup musik Al-Badar sebagai salah satu media dakwahnya. Pemimpin generasi ke empat saat ini Kiai Achmad Azaim Ibrahimy mendirikan kelompok seni Bhenning yang juga menjadi media dakwah, di dalam Bhenning ada ruang ekspresi sastra dalam penulisan naskah drama yang juga dipentaskan santri dan pengurus pesantren (Pujiati, 2018:40). Musik juga menjadi pengiring pertunjukan Bhenning, baik dalam pembacaan salawatan bersama ataupun sebagai ilustrasi. Fakta-fakta keterlibatan pemimpin pesantren Salafiyah Syafi'iyah dalam hal keilmuan yang militan di pesantren-pesantren dalam dan luar negeri, tradisi belajar yang runtut, perjuangan membela kemanusiaan dalam perjuangan melawan penjajah, kecintaan pada seni dan musik pun membentuk formasi wacana religius-humanis dalam ajarannya. Perihal keagamaan adalah yang utama, tetapi kemanusiaan juga tidak dinomorduakan. Keduanya berjalan beriringan. Dogma agama memang hukumnya mutlak, tetapi ada pengecualian-pengecualian yang tetap dijaga dalam hal keutamaan kemanusiaan. Seperti yang telah dilakukan Nanang pada Indy untuk mempertahankan janin yang didapatnya di luar pernikahan merupakan ruang bagi kemanusiaan. Akan tetapi bukan berarti ada toleransi atas apa yang telah dilarang agama. Dosa zina itu tetap diakui, tetapi itu merupakan tanggungan pelakunya, bukan dosa janin dalam kandungan Indy. Husna menolak pinangan Ustaz Fikri demi menjaga kesetiaan pada Azka, demi menjaga hati Azka tunangannya agar tidak tersakiti. Sejatinya menyakiti perasaan orang lain dalam konteks pertunangan mereka adalah kesibukan lain atas kesibukan yang telah tercipta sehingga bisa menimbulkan permasalahan. Menolak tawaran guru yang dihormati dan dipatuhinya pun dilakukan dengan hormat dan tanpa mengurangi pamor sang guru. Peristiwa tersebut dalam cerpen menunjukkan permasalahan manusia yang kompleks dan diatasi dengan keputusan kemanusiaan, tetapi tidak mengingkari ajaran agama dalam membuat keputusan dalam permasalahan. Sementara Lily juga tidak ikut salat berjamaah yang merupakan keutamaan dalam ajaran Islam. Akan tetapi kondisi tubuhnya yang sakit menggugurkan keutamaan tersebut. Peristiwaperistiwa dalam cerpen-cerpen oleh para santri pesantren Salaf tersebut terhubung secara diskursif dengan fakta-fakta pemimpin pesantren mereka menjalani pendidikan dalam hal; keseimbangan religius-humanis. Sebagai pemimpin, para pemimpin pesantren telah menanamkan pengetahuan akan religiusitas dan humanisme dalam praktik keseharian mereka yang menjadi panutan bagi para santri. Keagamaan dan kemanusiaan yang bukan dalam posisi hierarkis menjadi kebenaran dalam pengetahuan mereka.

Cerpen-cerpen yang ada dalam buletin 
pondok pesantren berlabel Salaf ini pun menghadirkan sastra dengan alur-alur cair terhadap hukum, ajaran-ajaran agama tidak menjadi sebuah ancaman yang sifatnya meneror pembaca dalam pilihan surganeraka. Justru nilai-nilai kemanusiaan yang muncul dalam kisah-kisah dengan penulis anonim tersebut. Semangat religius-humanis melalui sastra pesantren yang dihadirkan oleh Tanwirul Afkar pada edisi-edisi yang kami analisis ini dapat menjadi tameng masyarakat untuk menangkal radikalisme. Penguatan sisi kemanusiaan dengan dasardasar religiusitas yang kuat pada mereka yang muda dengan bahasa mereka ini adalah upaya yang perlu terus direproduksi. Kaum muda yang juga merupakan santri di lingkungan Salafiayah Syafii'iyah ini menunjukkan kenyataan berbeda dari apa yang dinyatakan Ayub Mursalin dan Ibnu Katsir dalam artikelnya karena kondisi mereka yang diteliti berbeda. Di pesantren Salafiyah Syafi'iyah Sukorejo ini di bawah pengawasan pemimpin pesantren dalam hal paparan ideologi radikal. Artinya, perkara radikalisme yang sangat mungkin tumbuh di kalangan muda dan urban seperti santrisantri sebuah pesantren dari berbagai daerah, desa, dan kota dari dalam dan luar negeri menjadi perhatian pemimpin. Upayaupaya pencegahan pun dilakukan. Kepedulian pemimpin pada yang ideologis untuk mencegah tumbuhnya radikalisme dalam lingkungannya ini senanda dengan apa yang diungkapkan Pengasuh Pondok
Pesantren Nurul Jadid Probolinggo-Jawa Timur, K.H. Zaini akan faktor-faktor pendorong radikalisme, yaitu ekonomi, politik, dan ideologi (Zaini, 2017). Pimpinan Salafiyah Syafi'iyah telah mengantisipasi santrinya dari tiga faktor tersebut. Disadari bahwa santri berasal dari berbagai latar status sosial, yang berarti kondisi perekonomian mereka beragam, penanaman nasionalisme sebagai sikap politis historis pesantren mengingat K.H. As'ad sebagai pendiri pesantren menjadi salah satu pejuang nasional dalam perebutan kemerdekaan Republik Indonesia dan pengawalan ideologi melalui sensor peredaran buku di lingkungan pesantren. Tidak sia-sia, wujud dari upaya ini muncul dalam bentuk karya sastra yang menggambarkan perspektif mereka dalam melihat dunia: agama dan kemanusiaan.

Buletin Tanwirul Afkar sendiri memiliki motto "Komprehensif, Moderat, dan Bertanggung Jawab", yang memang terlihat dalam tema-tema yang diangkat di tiap rubriknya. Buletin ini tidak membatasi diri pada persoalan fiqih saja, tetapi memberi ruang pula pada diskusi tentang permasalahan bangsa dan negara, ukhuwah dan etika relasi sosial, serta persoalan epistemologis. Sementara untuk sastra, ada rubrik khusus yang diberi nama Qawaid untuk memberi kesempatan bagi para santri untuk menulis cerita pendek. Penting untuk dipahami bahwa buletin Tanwirul Afkar bukan merupakan satusatunya wadah bagi para santri untuk menulis karya sastra. Tradisi kesusastraan nyatanya 
tumbuh subur di pesantren ini. Sanggar Seni Cermin yang pernah dianugerahi sebagai sanggar seni Cermin terbaik se-Jawa Timur (Romadhon, 2014) di bawah asuhan Zainul Walid konsisten dalam memberdayakan para santri untuk berkarya seni dan sastra melalui sekolah deklamasinya. Izzul Muttaqin, salah satu santri di Saafiyah Syafi'iyah, bahkan telah menerbitkan sebuah novel berjudul Menggapai Kosong dengan tema yang cukup berani dan tidak terkungkung dalam dogma yang kaku. Dalam novel ini, kebenaran agama serta keberadaan Tuhan dipertanyakan lewat kegelisahan tokoh utama dan teman diskusinya yang seorang ateis.

Kiprah para santri dalam dunia sastra ini kiranya merupakan salah satu jawaban atas apa yang diinginkan oleh pengasuh pesantren, K.H.R. As'ad Syamsul Arifin yang pernah berpesan, "Saya bercita-cita agar santri saya seperti santrinya Sunan Ampel, ada yang menjadi Fuqoha, Seniman, Negarawan, dan Waliyullah" (Romadhan, 2014). Dari paparan di atas, keberpihakan pesantren dan santrinya terhadap kemanusiaan mewujud pada kesusastraan beserta nilai humanis universal yang diusungnya sebagaimana direpresentasikan dalam ketiga cerpen yang menjadi objek kajian tulisan ini. Sama halnya dengan fungsi syiir yang dikemukakan Burhanudin (2017) bahwa sastra sebagai media pendidikan dan pengajaran nilai humanis dan religius merupakan representasi mental subjek masyarakat pesantren untuk dapat menyebarkannya kepada apresian.

\section{Kesimpulan}

Salaf yang menjadi batasan pada tataran fiqih (hukum) tidak dihadirkan dalam absolutisme kaku dalam cerpen-cerpen terbitan buletin pesantren Salafiyah Syafi'iyah terpilih ini. Karya sastra yang merupakan produk pemikiran tidak lahir dari imajinasi hampa, melainkan terhubung lurus dengan wacana dalam kehidupan nyata (Faruk, 2007) maka cerpen-cerpen tersebut merepresentasikan wacana yang sama dengan wacana dalam kehidupan nyata para santri Salafiyah Syafi'iyah Sukorejo dalam hal religiushumanis. Sastra pesantren tersebut sebagai produk kultural yang sekaligus memproduksi simbol-simbol kultural menunjukkan keberpihakan ideologis para santri terhadap persoalan kemanusiaan yang berjalan harmonis dengan nilai religiusitas yang diajarkan pada mereka selaku santri. Konsep Habluminallaah dan Habluminanaas berjalan seiring dalam perspektif santri melalui sastra pesantren. Alih-alih berkutat pada penghakiman dogmatis terhadap benar dan salah, wacana religius-humanis yang direpresentasi dalam sastra pesantren memberi ruang pada persoalan kemanusiaan secara proporsional seiring dengan konteks kulturalnya. Wacana religius-humanis dihadirkan sebagai solusi interpretasi fiqih yang kerap tekstual dalam cerpen. Sementara santri para penulis mendukung dan berusaha menyebarkan kearifan hidup dalam kerangka 
Poetika : Jurnal Ilmu Sastra

Vol. VII No. 1, Juli 2019
DOI 10.22146/poetika.40902

ISSN 2338-5383 (print) ; 2503-464 (online) aturan keagamaan yang linear antara habblumminallah-habblumminannas: ketuhan -an dan kemanusiaan. Dengan demikian pesantren yang kerap dipahami secara parsial sebagai institusi dengan aturan yang kaku, dogmatis sehingga cenderung intoleran dan dianggap ideal sebagai lahan subur bagi bibit radikalisme, dalam konteks kajian ini tidak terbukti. Tesis mengenai tradisi salaf yang digolongkan konservatif dalam pengajaran agama dan kerap dihubungkan dengan ruang persebaran radikalisme ternyata tidak berlaku di lingkungan Pondok Pesantren Salafiyah Syafiiyah Sukorejo Jawa Timur. Tiga cerpen yang kami analisis ini menunjukkan bahwa konservatisme tidak identik dengan radikalisme yang membahayakan tatanan sosial dan kemanusiaan, melainkan konservatisme ala mereka adalah soal keruntutan dan militansi belajar secara sistematis-historis mengenai hukum agama yang tidak terpisah dari kemanusiaan.

\section{Daftar Pustaka}

Anonim. 2017. "Cinta Sejati Itu Tidak Mudah". Cerpen dalam buletin Tanwirul Afkar edisi 532 April.

Anonim. 2013. "Di Antara Dua Pilihan". Cerpen dalam buletin Tanwirul Afkar edisi 505 April.

Faruk. 2007. Kuliah Pengantar Sosiologi Sastra di kelas sastra pascasarjana Ilmu humaniora FIB UGM.

Foucault, Michel. 1980. Power/Knowledge. Translated by Collin Gordon, Leo Marshal, John Mepham, and Kate Soper. (ed) Gordon, Collin. New York: Pantheon Books.
Foucault, Michel. 1981. "The Order of Discourse", Inaugural Lecture at the College de France, 6 Desember 1976, dipublikasikan kembali dalam Robert C. Young (ed). Untying the Text: A PostStructuralist Reader. Boston: Routledge \& Kegan Paul Ltd.

Foucault, Michel. 1984. "Truth and Power" dalam Paul Rainbow (ed). Foucault Reader. New York: Pantheon Books.

Hall, Stuart. 1997. Representation: Cultural Representation and Signifying Pratices. London: Sage Publication .

Haryatmoko. 2015. Membongkar Rezim Kepastian: Pemikiran Kritis PostStrukturalis. Yogyakarta: Penerbit Boekoe Tjap Petroek.

Lidchi, Henrietta.1997. "Poetics and Politics of Exhibiting of Other Cultures" dalam Hall Representation: Cultural Representation and Signifying Practices. London: Sage Publication.

Mursalin, Ayub. Katsir, Ibnu. 2010. "Pola Pendidikan Keagamaan Pesantren dan Radikalisme: Studi Kasus Pesantrenpesantren di Provinsi Jambi" dalam Kontekstualita, Vol.25, No.2: 255--290.

Pujiati, Hat. 2014. "Model Pengembangan Komunitas Sastra Berbasis Lokalitas: Meretas Jalan bagi Industri Kreatif Kesastraan di Wilayah Tapal Kuda". Lembaga Penelitian dan Pengabdian Universitas Jember.

2018. "Konstruksi Damai dalam Perspektif Santri: Model Kreativitas Sastra di Pesantren Berbasis Wacana Religius-Humanistik untuk Pencegahan Radikalisme". Lembaga Penelitian dan Pengabdian Universitas Jember

Anonim. 2013. "Seruas Bingung". Cerpen dalam buletin Tanwirul Afkar edisi 506 Sya'ban $1434 \mathrm{H}$.

Wilson, Chris. 2008. Ethno-Religious Violence in Indonesia: from Soil to God. London: Routledge.

\section{Daftar Laman}

Burhanudin, Muhammad. 2017. "Nilai Humanisme dan Religius Syiir Pesantren" dalam Jurnal Sastra Indonesia Volume 6 No.1: 35-42 http://journal.unnes.ac.id/ sju/index.php/jsi 
Rahman, Jamal D. 2008. "Sastra, Pesantren, dan Radikalisme". https:// jamaldrahman.wordpress.com/2008/1 0/25/sastra-pesantren-danradikalisme-islam/?wref=tp

Romadhan, Ilham. 2014. "Sukorejo dalam Kesusastraan Nasional". https:// fansgelap.wordpress.com/2014/04/14 /sukorejo-dalam-kesusastraan-nasional $-2 /$

\section{Wawancara}

Zia. 2017. Penanggungjawab toko buku di dalam lingkungan pesantren Slafiyah Syafi'iyah Sukorejo-Situbondo. Wawancara dilakukan dalam rangka penelitian Konstruksi Damai dalam Perspektif Santri: Model Kreativitas Sastra di Pesantren Berbasis Wacana ReligiusHumanistik untuk Pencegahan Radikalisme oleh Hat Pujiati dan Irana Astutiningsih, 